\title{
ENHANCING MICRO TEACHING TECHNIQUE THROUGH THE INCORPORATION OF LESSON STUDY: PERCEPTIONS OF INITIAL TEACHER EDUCATION MATHEMATICS STUDENTS AT CENTRAL UNIVERSITY OF TECHNOLOGY
}

\author{
Ratokelo Willie Thabane \\ Department of Educational and Professional Studies, \\ Central University of Technology, Free State (South Africa)
}

\begin{abstract}
Microteaching is a compulsory course in the initial teacher education programme at Central University of Technology. It is aimed at preparing students for teaching practice. Its key strength is to provide a supportive environment in which student teachers could practice their teaching skills in manageable portions, receive feedback on their performance, reflect on the feedback received and subsequently use the information received to improve on their teaching. Using lesson study, teachers have a means for planning, observing, and conferring with others. Lesson study is an initiative that aims to enhance teaching and learning through the methodology of professional sharing of practice. This study explored the perceptions of Initial Teacher Education (ITE) students on the effectiveness of Lesson study in improving micro teaching at the Central University of Technology. A total of 80 initial teacher education mathematics students in their third year of study participated in this study. A five-point Likert scale questionnaire with variables ranging from strongly disagree to strongly agree was used to explore the perceptions of ITE students on the effectiveness of lesson study in enhancing the acquisition of teaching skills. Results indicate that the lesson study approach is a viable ingredient in the process of micro teaching in that collaboration in lesson study reduced feelings of professional isolation; student teachers further reported a sharper focus on pupil learning and enhanced confidence in dealing with questions from pupils.
\end{abstract}

Keywords: Micro-teaching, lesson study, collaboration, observation of learning.

\section{Introduction}

Microteaching has been defined differently by different educationists. For example, D.W. Allen (1966) defined microteaching as a scaled down teaching encounter in class size and class time whereas R.N. Buch (1968) defined it as a teacher-education technique which allows teachers to apply clearly defined teaching skills to carefully prepared lessons in a planned series of five to ten minutes encounters with a small group of real students, often with an opportunity to observe the results on video tape. From these definitions microteaching is regarded as a skill-based analytical technique that is used in teacher education to bridge the gap between theory and practice in teaching (Taole, 2015). Microteaching is an organised, concentrated and scaled-down simulated teaching practice where a student teacher teaches a small portion of a lesson to a small group of his or her classmates (Taole, 2015). The usual complexities of the normal teaching encounter such as time, number of learners, content coverage and teaching skills are reduced, which makes it possible to concentrate on specific teaching behaviour and to practice teaching under controlled conditions. Microteaching is applicable for use by both pre-service and in-service teachers. Figure 1 below outlines the micro-teaching cycle.

Figure 1. The Micro-teaching Cycle.

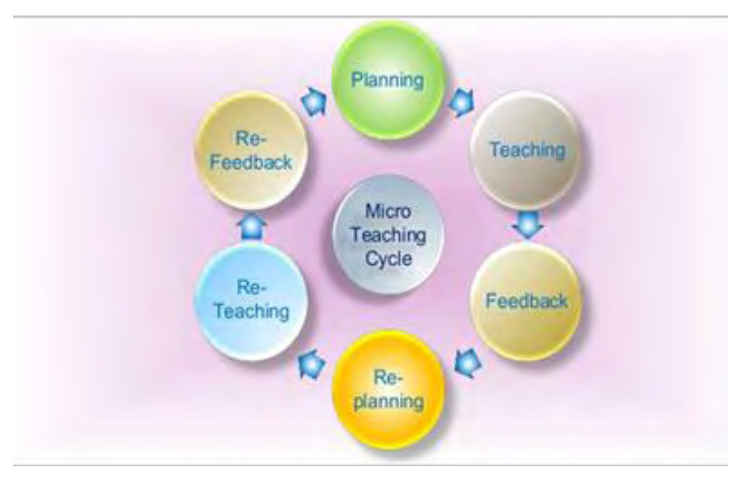


Lesson study on the other hand is defined by Lewis (2002) as a teacher-led instructional improvement cycle in which teachers work collaboratively to: formulate goals for student learning, plan a lesson, teach and/or observe the lesson, reflect on the gathered evidence, revise the lesson for improvement, and reteach the revised lesson.

According to Hart, Alston and Murata (2011) Lesson study has the following key characteristics:

1. Lesson study is centered around teachers' interests: Teachers' interests are central to their professional development. Lesson study goals should be something teachers feel is important to investigate and relevant to their own classroom practice.

2. Lesson study is student focused: Lesson study is about student learning. At any part of the lesson study cycle (Figure 2), the activities should focus teachers' attention to student learning and its connections to lessons/teaching.

3. Lesson study has a research lesson: Teachers have shared physical observation experiences (in some special cases, video may be used in place of the live lessons, but this is not recommended), that provide opportunities for teachers to be researchers.

4. Lesson study is a reflective process: Lesson study provides plenty of time and opportunities for teachers to reflect on their teaching practice and student learning, and the knowledge gained from and for the reflective practice should be shared in some format with the larger teaching and educational communities.

5. Lesson study is collaborative: Teachers work interdependently and collaboratively in lesson study.

Lesson study incorporates many characteristics of effective professional development programs identified in prior research: it is site-based, practice-oriented, focused on student learning, collaboration-based, and research-oriented (Hart, Alston \& Murata, 2011). It places teachers at the centre of the professional activity with their interests and a desire to better understand student learning based on their own teaching experiences. Hart, Alston and Murata (2011) further corroborate the structure and sequence of events outlined by Lewis (2002) by arguing that in lesson study: teachers organically come together with a shared question regarding their students'learning, plan a lesson to make student learning visible, and examine and discuss what they observe. Lesson study typically follows the steps outlined in Figure 2 below, with a research lesson (live lesson observation) as the centrepiece of the study process.

Mathematics student teachers were introduced to the lesson study approach. Small teams of student teachers worked together to design, teach, study, and refine a single class lesson. This work was expected to result in at least two tangible products: (a) a detailed, usable lesson plan, and (b) an in-depth study of the lesson that investigates teaching and learning interactions, explaining how students responded to instruction, and how instruction might be further modified based on the evidence collected. Cerbin and Koop (2006) adapted the original Japanese model and came up with a model of lesson study for the college classroom with the following key steps in implementing a lesson study: Formulating learning goals; designing the research lesson; designing the study; teaching and observing the research Lesson; analysing the evidence; repeating the process; and documenting the lesson study. Matanluk, Johari and Matanluk (2013) corroborate Cerbin and Koop's idea of the steps by suggesting the following steps as highlighted in figure 2:

Step 1: Plan a collaborative lesson plan

Teachers together plan and discuss in detail the content. Teachers share their experiences, observations and ideas, create lesson plans that are appropriate to the level of students to be taught. Teachers use various sources to produce a quality lesson plan using textbook, reference books and teaching guide.

Step 2: Implement a lesson in class

A teacher involved in the construction of lesson plans to teach groups of students who have been determined based on lesson plans that have been built. These lessons involve teachers in the Lesson Study group, other teachers act as observers, and a resource. Lesson plan used as a reference in the teaching.

Step3: Engage in discussion and reflect on teaching.

The teacher groups jointly make a reflection of the lesson plan after seeing the reality of teaching in the classroom. Discussions and sharing of ideas and clarifying what has been observed while submitting comments take place and suggestions for improvements are made. Consultants also offer comments and brainstorming.

Step 4: Modify the plan to teach

Teachers to modify and teach the lesson plan in order to learn something from this process. Modification in this step will result in better teaching program and details regarding all the weaknesses noted in the previous lesson. All modifications made to a joint decision and shall be agreed upon by all teachers.

Step 5: Teach the lesson plan that has been modified

Decisions are taken with the consent of the Lesson Study group members. If it is implemented, some members of the group become instructors and other teachers become observers.

Step 6: Shared reflections on a modified lesson plan 
The Lesson Study group will share suggestions, comments and ideas based on observations that were made a sin step three. The findings are then noted and recorded in order to make a resource that should guide teachers in the future.

Figure 2. The Lesson Study Cycle.

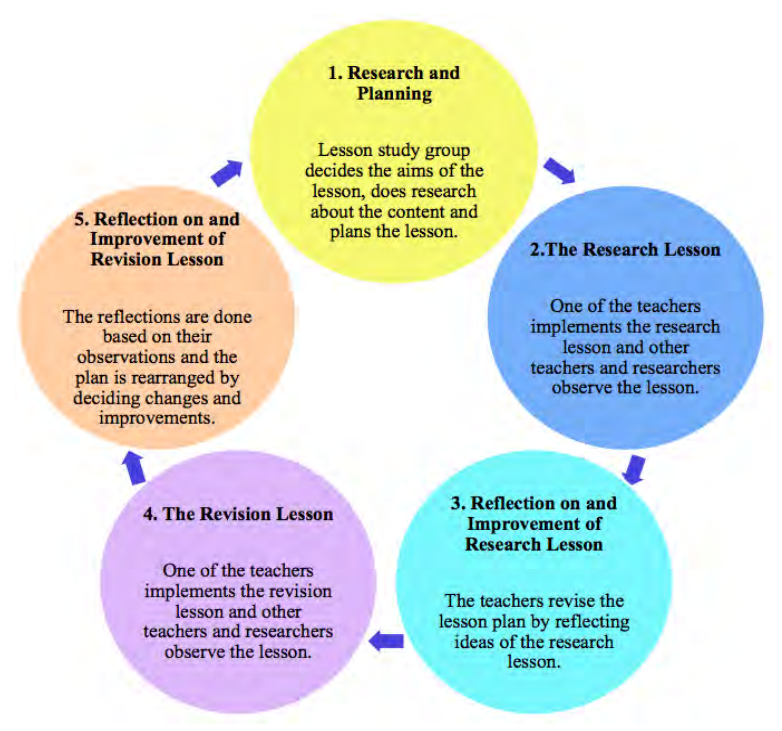

Lewis (2005) suggests that lesson study creates multiple "pathways for learning" that lead to instructional improvement. According to her model, teachers' thinking and practice may improve in multiple ways. This idea is corroborated by Lewis, Perry and Hurd (2009) who identify how the following aspects of the Lesson Study approach may produce instructional improvement: Investigation helps the team to consider students' current characteristics; consider long term goals for student learning and development; study the content area: key concepts, existing curricula, standards, learning trajectory, and research. Planning helps the team to select or develop research lesson; try task in order to anticipate student solutions; write up instructional plan, including goals for student learning and development, anticipated student thinking, data collection points, rationale for lesson design, connection to long-term goals. During the research stage, the team conducts the research lesson, and other members observe and collect data during live research lesson. Reflection helps the team to share and discuss data from research lesson in post- lesson colloquium; team members (and often other observers) draw out implications for lesson redesign, for teaching- learning more broadly, and for understanding of students and subject matter; summarize in writing what was learned from cycle, to consolidate the learning; and if need be revise and reteach the lesson.

According to Lewis (2004) teachers in Japan, where Lesson Study originated, identified seven pathways of improvement resulting from lesson study: knowledge of subject matter; knowledge of instruction; ability to observe students; collegial networks; connection of daily practice to long- term goals; motivation and sense of efficacy, and quality of teaching and learning. Lesson study in the view of Cerbin and Kopp (2006) encompasses the full complexity of teaching and learning in the context of a single class lesson. Essentially, teachers have opportunities to question, explore and reflect on every phase of the teaching and learning process.

\section{Methodology}

This study aims to examine perceptions of student teachers on the influence of the lesson study approach in the micro-teaching for mathematics student teachers at Central University of Technology, specifically on the influence that this approach has on student teachers' knowledge of subject matter, knowledge of instruction, ability to observe learners and their motivation and sense of efficacy as prospective teachers. Two micro-teaching groups consisting of 40 students each were selected for this study, but 76 students took part. The two groups were introduced to the Lesson Study approach and guided on how to implement it. These groups were further divided into teams of 6-8 students each. After their first presentation of their lessons in a micro-teaching session, qualitative methods were used to document student teachers' perceptions on the influence of the Lesson Study approach in micro-teaching.

To assess this influence participants were asked to each indicate the extent to which the incorporation of Lesson Study into micro-teaching has influenced the following aspects:

- knowledge of subject matter,

- knowledge of instruction,

- ability to observe students,

- motivation and sense of efficacy 
A questionnaire consisting of a five-point Likert scale ranging from 1 (Strongly Disagree) to 5 (Strongly Agree) was used to report their responses

\section{Findings}

This study examines the perceptions of mathematics student teachers at Central University of Technology on the influence of the lesson study approach in the presentation of their micro-lessons. Seventy-six (76) questionnaires were received from the student teachers. The study findings are based on information from questionnaires distributed to third year mathematics student teachers. The researcher's priority was on the influence of the lesson study approach on the student teachers' knowledge of subject matter; knowledge of instruction; ability of student teachers to observe learners; and their motivation and sense of efficacy as prospective mathematics teachers.

Table 1. Knowledge of Content: a teacher's understanding and application of the current theories, principles, concepts and skills of a discipline.

\begin{tabular}{|c|c|c|c|c|c|}
\hline Characteristics developed & $\begin{array}{l}\text { Strongly } \\
\text { Disagree } \\
\end{array}$ & Disagree & $\begin{array}{l}\text { Not } \\
\text { Sure }\end{array}$ & Agree & $\begin{array}{l}\text { Strongly } \\
\text { Agree }\end{array}$ \\
\hline $\begin{array}{l}\text { Lesson Study has helped me to: } \\
\text { (i) demonstrate an understanding and in-depth knowledge of content } \\
\text { and maintains an ability to convey this content to students. }\end{array}$ & 3 & 14 & 15 & 35 & 9 \\
\hline $\begin{array}{l}\text { (ii) maintain on-going knowledge and awareness of current content } \\
\text { developments. }\end{array}$ & 6 & 12 & 13 & 39 & 6 \\
\hline (iii) design standards-based lessons/units & 4 & 16 & 10 & 43 & 3 \\
\hline $\begin{array}{l}\text { (iv) demonstrate high quality teaching and learning content through } \\
\text { the use of ICT }\end{array}$ & 7 & 11 & 8 & 45 & 5 \\
\hline $\begin{array}{l}\text { (v) use and promote the understanding of appropriate content } \\
\text { vocabulary. }\end{array}$ & 3 & 10 & 13 & 41 & 9 \\
\hline $\begin{array}{l}\text { (vi) access a rich repertoire of instructional practices/strategies and } \\
\text { apply them appropriately }\end{array}$ & 2 & 9 & 12 & 46 & 7 \\
\hline
\end{tabular}

Table 1 shows that about $58 \%$ of the student teachers agreed that lesson study helped them to demonstrate an understanding and in-depth knowledge of content and maintains an ability to convey this content to students, and about $59 \%$ of them agree that it helped them to maintain on-going knowledge and awareness of current content developments. Lesson study also helped them to design standards-based lessons or units (about 61\%); demonstrate high quality teaching and learning content through the use of ICT (66\%); use and promote the understanding of appropriate content vocabulary (66\%); and access a rich repertoire of instructional practices/strategies and apply them appropriately (70\%).

Table 2. knowledge of instruction: a teacher supports and encourages a student's commitment to initiate and complete complex, inquiry-based learning requiring creative and critical thinking with attention to problem solving.

\begin{tabular}{|c|c|c|c|c|c|}
\hline Characteristics developed & $\begin{array}{l}\text { Strongly } \\
\text { Disagree }\end{array}$ & Disagree & $\begin{array}{l}\text { Not } \\
\text { Sure }\end{array}$ & Agree & $\begin{array}{l}\text { Strongly } \\
\text { Agree }\end{array}$ \\
\hline $\begin{array}{l}\text { Lesson Study has helped me to: } \\
\text { (i) instruct the complex processes, concepts and principles contained in } \\
\text { state and national standards using differentiated strategies that make } \\
\text { instruction accessible to all students. }\end{array}$ & 5 & 6 & 8 & 45 & 12 \\
\hline $\begin{array}{l}\text { (ii) scaffold instruction to help students to reason and develop problem- } \\
\text { solving strategies. }\end{array}$ & 8 & 7 & 7 & 44 & 10 \\
\hline $\begin{array}{l}\text { (iii) orchestrate effective classroom discussions, questioning, and } \\
\text { learning tasks that promote higher order thinking skills. }\end{array}$ & 6 & 4 & 10 & 42 & 14 \\
\hline (iv) provide meaningful learning opportunities for students. & 2 & 5 & 8 & 52 & 9 \\
\hline (v) provide meaningful learning opportunities for students & 4 & 4 & 13 & 42 & 13 \\
\hline $\begin{array}{l}\text { (vi) integrate a variety of learning resources with classroom instruction } \\
\text { to increase learning options. }\end{array}$ & 5 & 3 & 19 & 37 & 12 \\
\hline $\begin{array}{l}\text { (vii) structure and facilitate ongoing formal and informal discussions } \\
\text { based on a shared understanding of rules and discourse }\end{array}$ & 3 & 4 & 7 & 43 & 19 \\
\hline $\begin{array}{l}\text { (viii) integrate the application of inquiry skills into learning } \\
\text { experiences. }\end{array}$ & 2 & 5 & 18 & 40 & 11 \\
\hline $\begin{array}{l}\text { (ix) clarify and share with students learning intentions/targets and } \\
\text { criteria for success. }\end{array}$ & 1 & 4 & 12 & 51 & 8 \\
\hline
\end{tabular}

Table 2 shows that $75 \%$ of the student teachers believed that the lesson study approach helped them to instruct the complex processes, concepts and principles contained in state and national standards using differentiated strategies that make instruction accessible to all students. Seventy-one percent (71\%) of them agreed that it helped them to scaffold instruction to help students to reason and develop problem-solving strategies. Sixty-five percent (65\%) of the student teachers in this study believed that lesson-study approach helped them to orchestrate effective classroom discussions, questioning, and learning tasks that promote higher-order thinking skills. Student teachers also believed that lesson study approach helped them to provide meaningful learning opportunities for students (83\%); provide meaningful learning opportunities for students (72\%); integrate a variety of learning resources with classroom instruction to increase learning options (65\%); structure and facilitate ongoing formal and 
informal discussions based on a shared understanding of rules and discourse (82\%); integrate the application of inquiry skills into learning experiences (67\%); and clarify and share with students learning intentions/targets and criteria for success $(78 \%)$.

Table 3. Ability to observe students.

\begin{tabular}{|c|c|c|c|c|c|}
\hline Characteristics developed & $\begin{array}{l}\text { Strongly } \\
\text { Disagree }\end{array}$ & Disagree & $\begin{array}{l}\text { Not } \\
\text { Sure }\end{array}$ & Agree & $\begin{array}{l}\text { Strongly } \\
\text { Agree }\end{array}$ \\
\hline $\begin{array}{l}\text { Lesson Study has helped me to: } \\
\text { (i) focus on how students respond to the lesson, }\end{array}$ & 5 & 8 & 12 & 44 & 7 \\
\hline (ii) gather rich evidence related to the learning goal during the lesson & 1 & 6 & 17 & 47 & 5 \\
\hline $\begin{array}{l}\text { (iii) record detailed field notes, or use checklists or rubrics to } \\
\text { categorize or monitor student engagement, performance, thinking, } \\
\text { and/or behaviour }\end{array}$ & 3 & 7 & 10 & 47 & 9 \\
\hline (iv) focus on specific types of student activity & 6 & 9 & 13 & 36 & 12 \\
\hline $\begin{array}{l}\text { (v) use checklists or rubrics to categorize or monitor student } \\
\text { engagement, performance, thinking, and/or behaviour }\end{array}$ & 3 & 10 & 9 & 42 & 12 \\
\hline
\end{tabular}

Table 3 on the other hand shows that $67 \%$ of the student teachers agreed that lesson study approach helped them to focus on how students respond to the lesson. Student teachers further believed that lesson study approach helped them to gather rich evidence related to the learning goal during the lesson $(68 \%)$; record detailed field notes, or use checklists or rubrics to categorize or monitor student engagement, performance, thinking, and/or behaviour (74\%); record detailed field notes, or use checklists or rubrics to categorize or monitor student engagement, performance, thinking, and/or behaviour (73\%); focus on specific types of student activity (63\%); and use checklists or rubrics to categorize or monitor student engagement, performance, thinking, and/or behaviour (74).

Table 4. Motivation and sense of efficacy.

\begin{tabular}{|c|c|c|c|c|c|}
\hline Characteristics developed & $\begin{array}{l}\text { Strongly } \\
\text { Disagree }\end{array}$ & Disagree & Not Sure & Agree & $\begin{array}{l}\text { Strongly } \\
\text { Agree }\end{array}$ \\
\hline $\begin{array}{l}\text { Lesson Study has helped me to: } \\
\text { (i) Believe in my ability to teach effectively }\end{array}$ & 3 & 8 & 11 & 36 & 18 \\
\hline (ii) believe in the ability of my students to learn & 5 & 6 & 9 & 41 & 15 \\
\hline (iii) create environments conducive to learning & 2 & 4 & 7 & 47 & 16 \\
\hline
\end{tabular}

Table 4 shows that $71 \%$ of the student teachers agreed that lesson study approach helped them to believe in their ability to teach effectively. They also agreed that lesson study approach helped them to believe in the ability of my students to learn (74\%); and create environments conducive to learning $(83 \%)$.

\subsection{Conclusion}

The findings of this study indicate that the perceptions of student teachers on the influence of lesson study on micro-teaching are positive. Through the incorporation of lesson study aspects in micro-teaching enhance the student teachers' understanding and application of the current theories, principles, concepts and skills of a discipline; their ability to support and encourage their learners' commitment to initiate and complete complex, inquiry-based learning requiring creative and critical thinking with attention to problem solving. It further enhances their ability to observe learners and their motivation and sense of efficacy as prospective teachers.

The findings further suggest that lesson study has a place in the repertoire of teacher learning approaches and that there is evidence that its use can improve teaching, learning and pupil learning outcomes in a range of school contexts.

\section{References}

Hart, L.C., Alston, A.S. \& Murata, A. (Eds). 2011. Lesson Study Research and Practice in Mathematics Education: Learning together. London. Springer

Lewis, C. (2002). Lesson study: A handbook of teacher-led instructional change. Philadelphia, PA: Research for Better Schools.

Lewis, C. (2005). How do teachers learn during lesson study? In P. Wang-Iverson \& M. Yoshida (Eds.). Building our understanding of lesson study. Philadelphia: Research for Better Schools, Inc.

Lewis, C.C., Perry, R.R. \& Hurd, J. 2009. Improving mathematics instruction through lesson study: a theoretical model and North American case. Springer Science+Business Media B.V. Published Online: 18 April 2009.

Matanluk, K., Johari, K. \& Matanluk, O. 2013.The Perception of Teachers and Students toward Lesson Study Implementation at Rural School of Sabah: A Pilot Study. Procedia - Social and Behavioral Sciences 90, 245-250. Doi: 10.1016/j.sbspro.2013.07.088. 